\title{
COVID-19: Antiviral Agents, Antibody Development and Traditional Chinese Medicine
}

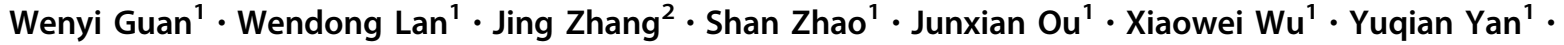 \\ Jianguo $\mathrm{Wu}^{2} \cdot$ Qiwei Zhang ${ }^{1,2}$ (1)
}

Received: 3 July 2020 / Accepted: 31 August 2020 / Published online: 30 September 2020

(c) Wuhan Institute of Virology, CAS 2020

\begin{abstract}
The World Health Organization (WHO) has declared coronavirus disease 2019 (COVID-19) is the first pandemic caused by coronavirus named severe acute respiratory syndrome coronavirus 2 (SARS-CoV-2). Currently, there is no effective anti-SARS-CoV-2 drug approved worldwide for treatment of patients with COVID-19. Therapeutic options in response to the COVID-19 outbreak are urgently needed. To facilitate the better and faster development of therapeutic COVID-19 drugs, we present an overview of the global promising therapeutic drugs, including repurposing existing antiviral agents, network-based pharmacology research, antibody development and traditional Chinese medicine. Among all these drugs, we focus on the most promising drugs (such as favipiravir, tocilizumab, SARS-CoV-2 convalescent plasma, hydroxychloroquine, Lianhua Qingwen, interferon beta-1a, remdesivir, etc.) that have or will enter the final stage of human testing-phase III-IV clinical trials.
\end{abstract}

Keywords Severe acute respiratory syndrome coronavirus 2 (SARS-CoV-2) - Coronavirus disease 2019 (COVID-19) . Updates $\cdot$ Drug repositioning $\cdot$ Network-based pharmacology $\cdot$ Antibody $\cdot$ Traditional Chinese medicine

\section{Introduction}

Since the end of 2019, an increasing cases of pneumonia were reported in Wuhan, followed by other cities and provinces in China as well as many other countries (Huang C et al. 2020). On 7 January 2020, a novel coronavirus (2019-nCoV) was initially isolated from a patient and then the complete genome was analyzed (Zhu et al. 2020). Later, this novel coronavirus was identified as the cause and named SARS-CoV-2 officially by the International Committee on Taxonomy of Viruses (ICTV). On January 30, 2020, WHO declared the coronavirus outbreak become a public-health emergency of international concern

Qiwei Zhang

zhangqw@jnu.edu.cn

1 Guangdong Provincial Key Laboratory of Tropical Disease Research, School of Public Health, Southern Medical University, Guangzhou 510515, China

2 Guangdong Provincial Key Laboratory of Virology, Institute of Medical Microbiology, Jinan University, Guangzhou 510632, Guangdong, China
(PHEIC) (Ko et al. 2020). On February 11, 2020, WHO announced a name for this new coronavirus disease caused by SARS-CoV-2 infection: coronavirus disease 2019 (COVID-19) (Gorbalenya et al. 2020). Soon, the viruses have spread to many countries, including Asia, Europe, Americas, and Australia. On March 11, WHO characterized COVID-19 as a pandemic. As of September 2, 2020, 25,602,665 confirmed cases of COVID-19 have been reported globally and 852,758 people are dead due of COVID-19, with the estimated fatality rate of $3.33 \%$ (WHO 2020). This on-going COVID-19 pandemic has become the most serious threat to public health in recent times.

Given that large and increasing numbers of COVID-19 cases, the therapeutic options in response to the pandemic and effective interventions for severe cases are urgently needed. So far, there is no specific prescription drug available for its general use to alleviate the severity of COVID-19. SARS-CoV-2 is an enveloped, positive-sense, single-stranded RNA coronavirus belonging to the genus Betacoronavirus. As the genus also contains other similar high-pathogenic SARS-CoV and MERS-CoV (Chan et al. 
2020), the experiences in the development of antibetacoronaviruses may facilitate the COVID-19 drug development. Several existing and potential drug candidates, including chloroquine and remdesivir, have been tested and the clinical trials showed different efficacy. Here, we present an update of the progress of therapeutic drug development towards COVID-19, including repurposing existing antiviral agents, network-based pharmacology research, antibody development and traditional Chinese medicine (Table 1).

\section{Drug Repositioning}

Given that the discovery and marketing of new compounds often require months to years, existing prescription drugs have matured synthetic processes, known safety and pharmacokinetic data, which greatly reduces costs and time (Guo 2020). Broad-spectrum antiviral drugs are the first choice for new use of old drugs. For example, SARS-CoV and SARS-CoV-2 share 96\% RNA-dependent RNA polymerase (RdRp) sequence identity (Gao et al. 2020). Therefore, drugs targeting viral RdRp proteins of SARS$\mathrm{CoV}$ are likely to be effective for SARS-CoV-2. In addition, human angiotensin-converting enzyme 2 (ACE2) inhibitors may also have an inhibitory effect on the virus because ACE2 is a cell surface receptor of both SARS$\mathrm{CoV}$ and SARS-CoV-2. The inhibition of ACE2 can block virus invasion into cells (Gao et al. 2020).

Here, we summarize and discuss selected candidates with a focus on approved drugs or experimental agents that have been already tested in clinical trials for other diseases, e.g., HIV, influenza, SARS and MERS. The potential to repurpose existing antiviral agents approved or in development for treating infections have been discussed.

\section{Remdesivir}

Remdesivir, targeting RNA-dependent RNA polymerase ( $R d R p)$, is a nucleotide analogue. It is a broad-spectrum antiviral drug developed by Gilead Science Inc. Remdesivir can be effectively metabolised to active nucleoside triphosphate in several human cell lines (Agostini et al. 2018). An in vitro study has demonstrated that nucleoside triphosphate works as an incorporation competitor with adenosine triphosphate, confuses viral RdRp, acts as a delayed RNA chain terminator against virus (Warren et al. 2016). It evades proofreading by viral exoribonuclease, and causes a decrease in viral RNA production (Agostini et al. 2018). In vitro tests, remdesivir has antiviral activity on various of viruses, including Ebola virus, coronavirus, hepatitis C virus, and HIV (Tchesnokov et al. 2019; Sheahan et al. 2020).
Recently, the antiviral activity of remdesivir was demonstrated at the stage after virus entry into Vero E6 cells, supporting its antiviral mechanism as a nucleotide analogue (Wang M et al. 2020). In February, 2020, the New England Journal of Medicine (NEJM) reported the first successful use of remdesivir to reverse the lung injury caused by COVID-19 (Holshue et al. 2020). Symptoms were significantly reduced the next day and oxygen saturation was $94 \%$ to $96 \%$. Other symptoms except dry cough were eliminated and finally the patient was discharged from the hospital. Although this reported only one case, it brings great hope to the clinical cure of COVID-19 by remdesivir. The pharmacodynamics results of the remdesivir are as follows: $\mathrm{EC}_{50}=0.77 \mu \mathrm{mol} / \mathrm{L} ; \mathrm{CC}_{50}>100 \mu \mathrm{mol} / \mathrm{L}$; selection index (SI) $>129.87 ; \mathrm{EC}_{90}=1.76 \mu \mathrm{mol} / \mathrm{L}$. Cohen suggested in Science that the combination of remdesivir and monoclonal antibody is likely to be the ideal therapy for COVID-19 (Cohen 2020).

Two phase III trials were initiated in early February to evaluate intravenous remdesivir (200 $\mathrm{mg}$ on day 1 and $100 \mathrm{mg}$ once daily for 9 days) in patients with COVID-19 (Wang $\mathrm{M}$ et al. 2020). Preliminary results indicate that patients who received remdesivir had a $31 \%$ faster time to recovery than those who received placebo $(P<0.001)$. Specifically, the median time to recovery was 11 days for patients treated with remdesivir compared with 15 days for those who received placebo. Results also suggested a survival benefit, with a mortality rate of $8.0 \%$ for the group receiving remdesivir versus $11.6 \%$ for the placebo group $(P=0.059)$. The result shows remdesivir was better than placebo from the perspective of the primary endpoint, time to recovery, a metric often used in influenza trials. Recovery in this study was defined as being well enough for hospital discharge or returning to normal activity level (NIH 2020). But this dose regimen of intravenous remdesivir did not provide significant clinical or antiviral effects in seriously ill patients with COVID-19. However, we could not exclude clinically meaningful differences and saw numerical reductions in some clinical parameters. Ongoing studies with larger sample sizes will continue to inform our understanding of the effect of remdesivir on COVID-19 (Wang YM et al. 2020).

\section{Chloroquine/Hydroxychloroquine}

Chloroquine was a front-line drug for the treatment and prophylaxis of malaria and is one of the most prescribed drugs worldwide (White et al. 2014). Yet the activity of the molecule is not limited to malaria and the control of inflammatory processes, as illustrated by its broadspectrum activity against a range of bacterial, fungal and viral infections (Raoult et al. 1990, 1999; Boulos et al. 2004; Rolain et al. 2007). Studies have shown that 
Table 1 Chemical drugs in clinical registrations to treat COVID-19.

\begin{tabular}{|c|c|c|c|c|c|}
\hline Name & Original indication & Target & $\begin{array}{l}\text { Clinical } \\
\text { trials } \\
\text { reported }\end{array}$ & Dose/administration & $\begin{array}{l}\text { Toxicities/side } \\
\text { effects }\end{array}$ \\
\hline \multicolumn{6}{|l|}{ Western medicine } \\
\hline Remdesivir & $\begin{array}{l}\text { Ebola virus disease } \\
\text { (Phase II); }\end{array}$ & $\begin{array}{l}\text { RNA-dependent } \\
\text { RNA polymerase } \\
\text { inhibitor }\end{array}$ & Yes & $\begin{array}{l}\text { A } 10 \text {-day course of remdesivir } \\
\text { treatment, } 200 \mathrm{mg} \text { intravenously on } \\
\text { day } 1,100 \mathrm{mg} \text { for next } 9 \text { days }\end{array}$ & $\begin{array}{l}\text { None noted (similar } \\
\text { to placebo in } \\
\text { severe COVID } \\
\text { patients) }\end{array}$ \\
\hline $\begin{array}{l}\text { Chloroquine/ } \\
\text { Hydroxychloroquine }\end{array}$ & Malaria treatment & $\begin{array}{l}\text { Caps hemozoin to } \\
\text { prevent } \\
\text { biocrystallization } \\
\text { of heme, PLpro } \\
\text { inhibitor }\end{array}$ & Yes & $\begin{array}{l}\text { Chloroquine: } 500 \mathrm{mg} \text { daily for } \\
10 \text { days } \\
\text { HCQ: weight }>50 \mathrm{~kg}, 500 \mathrm{mg} \times 2 / \\
\mathrm{d} \text { for } 7 \text { days; weight }<50 \mathrm{~kg} \text {, } \\
500 \mathrm{mg} \times 2 / \mathrm{d} \text { on days } 1 \sim 2 \text {, } \\
500 \mathrm{mg} / \mathrm{d} \text { on days } 3 \sim 7 \text {; }\end{array}$ & $\begin{array}{l}\text { Hemolytic anemia, } \\
\text { cardiomyopathy, } \\
\text { neutropenia, GI } \\
\text { disturbances, } \\
\text { retinopathy, rash, } \\
\text { QT prolongation }\end{array}$ \\
\hline Lopinavir/ritonavir & $\begin{array}{l}\text { A fixed dose } \\
\text { combination for } \\
\text { HIV/AID treatment }\end{array}$ & $\begin{array}{l}\text { Lopinavir: protease } \\
\text { inhibitor } \\
\text { Ritonavir: protease } \\
\text { inhibitor and } \\
\text { inhibitor of } \\
\text { CYP3A4 }\end{array}$ & Yes & Oral, $400 \mathrm{mg} / 100 \mathrm{mg}$, twice daily & $\begin{array}{l}\text { QT prolongation, } \\
\text { CV events, } \\
\text { dyslipidemia, } \\
\text { liver injury, GI } \\
\text { disturbances }\end{array}$ \\
\hline Arbidol & Influenza treatment & $\begin{array}{l}\text { Inhibits viral entry } \\
\text { by interfering with } \\
\text { clathrin-dependent } \\
\text { trafficking }\end{array}$ & Yes & $200 \mathrm{mg} \times 3 / \mathrm{d}$ for no more than $10 \mathrm{~d}$ & $\begin{array}{l}\text { No significant } \\
\text { differences } \\
\text { between ARB- } \\
\text { treated and control } \\
\text { groups }\end{array}$ \\
\hline Teicoplanin & $\begin{array}{l}\text { A glycopeptide } \\
\text { antibiotic to treat } \\
\text { bacterial infection }\end{array}$ & $\begin{array}{l}\text { Inhibits viral entry } \\
\text { by inhibiting the } \\
\text { activity of } \\
\text { cathepsin L }\end{array}$ & No & & $\begin{array}{l}\text { does not have dose- } \\
\text { related adverse } \\
\text { effects in the dose } \\
\text { range } 3-10 \mathrm{mg} / \mathrm{kg}\end{array}$ \\
\hline Glycyrrhizic Acid & $\begin{array}{l}\text { An extract of a } \\
\text { traditional Chinese } \\
\text { herb to treat } \\
\text { coughs, colds and } \\
\text { disturbed digestion }\end{array}$ & $\begin{array}{l}\text { Regulate immune } \\
\text { function, can bind } \\
\text { to ACE2 }\end{array}$ & Yes & $\begin{array}{l}250 \mathrm{mg} \text { standardized extract }(25 \% \\
\text { Glycyrrhizin-62.5 mg) for } \\
10 \text { days }\end{array}$ & $\begin{array}{l}\text { mild hypertension, } \\
\text { cytotoxicity and } \\
\text { bone damage }\end{array}$ \\
\hline Darunavir & $\begin{array}{l}\text { A fixed dose } \\
\text { combination for } \\
\text { HIV/AID treatment }\end{array}$ & $\begin{array}{l}\text { 3CL protease } \\
\text { inhibitor, substrate } \\
\text { of CYP3A4 }\end{array}$ & Yes & $800 \mathrm{mg} /$ days & $\begin{array}{l}\text { Liver injury, } \\
\text { dyslipidemia, } \\
\text { sulfonamide } \\
\text { allergy }\end{array}$ \\
\hline $\begin{array}{l}\text { Forsythin and } \\
\text { Chlorogenic acid }\end{array}$ & $\begin{array}{l}\text { Extract of a } \\
\text { traditional Chinese } \\
\text { herb to treat } \\
\text { influenza }\end{array}$ & ACE2 inhibitor & No & & \\
\hline Tocilizumab & $\begin{array}{l}\text { Commonly used for } \\
\text { rheumatoid arthritis } \\
\text { (RA) and cytokine- } \\
\text { release syndrome } \\
\text { induced by } \\
\text { chimeric antigen } \\
\text { receptor-T cell } \\
\text { therapy }\end{array}$ & $\begin{array}{l}\text { FCGR3A, IL6R, } \\
\text { CD69,GALNT18 }\end{array}$ & Yes & $4-8 \mathrm{mg} / \mathrm{kg}$ body weight & $\begin{array}{l}\text { Thrombocytopenia, } \\
\text { liver injury, } \\
\text { neutropenia, rash, } \\
\text { hypertension, } \\
\text { infection }\end{array}$ \\
\hline Interferon beta- $1 \mathrm{~b}$ & & $\begin{array}{l}\text { Pharmacogenomics } \\
\text { determinants are } \\
\text { not well- } \\
\text { delineated for } \\
\text { IFN- } \beta 1 \mathrm{~b}\end{array}$ & Yes & $\begin{array}{l}8 \text { million IU }(0.25 \mathrm{mg}) \text { on alternate } \\
\text { days }\end{array}$ & $\begin{array}{l}\text { Liver injury, } \\
\text { depression, heart } \\
\text { failure, } \\
\text { leukopenia, and } \\
\text { flu-like symptoms, } \\
\text { etc. }\end{array}$ \\
\hline
\end{tabular}


Table 1 (continued)

\begin{tabular}{|c|c|c|c|c|c|}
\hline Name & Original indication & Target & $\begin{array}{l}\text { Clinical } \\
\text { trials } \\
\text { reported }\end{array}$ & Dose/administration & $\begin{array}{l}\text { Toxicities/side } \\
\text { effects }\end{array}$ \\
\hline Dexamethasone & $\begin{array}{l}\text { First-line treatment } \\
\text { for immune-related } \\
\text { complications }\end{array}$ & $\begin{array}{l}\text { Suppresses the } \\
\text { immune system by } \\
\text { inhibiting naive T } \\
\text { cell proliferation } \\
\text { and differentiation }\end{array}$ & Yes & $6 \mathrm{mg}$ once daily for 10 days & $\begin{array}{l}\text { Mild increase of } \\
\text { blood glucose } \\
\text { level, ocular } \\
\text { hypertension, and } \\
\text { cataract, mood } \\
\text { and behavior } \\
\text { change, } \\
\text { osteoporosis }\end{array}$ \\
\hline \multicolumn{6}{|c|}{ Traditional Chinese medicine } \\
\hline $\begin{array}{l}\text { Qingfei Paidu } \\
\text { Decoction }\end{array}$ & $\begin{array}{l}\text { A traditional Chinese } \\
\text { medicine for } \\
\text { treating exogenous } \\
\text { fever caused by } \\
\text { cold evil }\end{array}$ & $\begin{array}{l}\text { The network } \\
\text { pharmacology } \\
\text { analysis showed } \\
\text { that QPD has an } \\
\text { overall regulatory } \\
\text { effect via multi- } \\
\text { component and } \\
\text { multi-target }\end{array}$ & Yes & & \\
\hline $\begin{array}{l}\text { Qingfei dayuan } \\
\text { granules \& Chaihu } \\
\text { daxiong mixture }\end{array}$ & $\begin{array}{l}\text { For COVID-19 } \\
\text { patients with severe } \\
\text { cough, sputum, and } \\
\text { wheezing }\end{array}$ & & No & & \\
\hline $\begin{array}{l}\text { Huashi Baidu } \\
\text { Granules }\end{array}$ & $\begin{array}{l}\text { First approval drug of } \\
\text { traditional Chinese } \\
\text { medicine for the } \\
\text { clinical treatment } \\
\text { of COVID-19 }\end{array}$ & $\begin{array}{l}\text { Eliminate } \\
\text { inflammation, } \\
\text { improve immunity }\end{array}$ & Yes & & \\
\hline Lianhuaqingwen & $\begin{array}{l}\text { As traditional } \\
\text { Chinese medicine } \\
\text { formula to treat } \\
\text { influenza }\end{array}$ & $\begin{array}{l}\text { Inhibits the SARS- } \\
\text { COV-2 } \\
\text { replication, affects } \\
\text { virus morphology } \\
\text { and exerts anti- } \\
\text { inflammatory } \\
\text { activity in vitro }\end{array}$ & Yes & 4 capsules, 3 times a day, after meal & $\begin{array}{l}\text { No toxic side } \\
\text { effects in mice }\end{array}$ \\
\hline
\end{tabular}

The information is retrieved from the Chinese Clinical Trial Registry (http://www.chictr.org.cn/index.aspx) and Clinicaltrials.gov as of May 27th, 2020.

chloroquine has inhibitory activity on SARS-CoV and MERS-CoV infection in vitro (Vincent et al. 2005; Savarino et al. 2006; Dyall et al. 2014).

Researchers tested the pharmacodynamics of chloroquine against SARS-CoV-2 in vitro, and the results showed that $\mathrm{EC}_{50}=1.13 \mu \mathrm{mol} / \mathrm{L} ; \mathrm{EC}_{90}=6.90 \mu \mathrm{mol} / \mathrm{L}$ (Wang $\mathrm{M}$ et al. 2020). Due to its tolerability, rare toxicity reports, inexpensive cost and immunomodulatory properties (Savarino et al. 2003), chloroquine is currently among the best available candidates to impact the severity of SARSCoV-2 infections in humans. Chloroquine phosphate has also been recommended in "Guideline on diagnosis and treatment of COVID-19 (Trial 7th edition)" (National Health Commission of the People's Republic of China 2020b; in Chinese). Currently, at least ten clinical trials are testing chloroquine as an anti-COVID-19 therapy (Harrison 2020). However, the study by Boulware et al. reporting a randomized trial testing hydroxychloroquine as postexposure prophylaxis for COVID-19 showed that hydroxychloroquine failed to show efficacy for COVID-19 prophylaxis (Boulware et al. 2020). The recent study published in Lancet reported a multinational, observational, real-world study of patients with COVID-19 requiring hospitalization, and found that the use of a regimen containing hydroxychloroquine or chloroquine (with or without a macrolide) was associated with no evidence of benefit, but instead was associated with an increase in the risk of ventricular arrhythmias and a greater hazard for inhospital death with COVID-19 (Mehra et al. 2020). However, on 4 June 2020, the Lancet published an update that the study authors retracted the study for publication due to lack of access to the databases needed for the investigation. The major doubts of the Lancet's retracted paper included: (1) The study was not a strict randomized double-blind 
control; (2) The study did not indicate the patient's health status before the trial; (3) The daily dosage of hydroxychloroquine exceeded the standard of $600 \mathrm{mg}$ (U.S. official recommended dosage is less than $500 \mathrm{mg}$ ); (4) The data from Australian medical institutions is inaccurate; (5) The original data lacks transparency.

On May 28 2020, Dr. Nanshan Zhong's research team published a clinical study of multi-center chloroquine treatment of COVID-19 in National Science Review. They found that after $500 \mathrm{mg}$ chloroquine oral administration twice a day (full dose), COVID-19 patients can clear the virus faster, allowing patients to recover body temperature more quickly; and the adverse events occurred were not different from the control group, and no serious adverse events occurred. $500 \mathrm{mg}$ chloroquine once a day (half dose) is also effective, and the adverse events are $40 \%$ lower than the full dose group. Therefore, the researchers believed that chloroquine is effective in treating patients with COVID-19 (Huang M et al. 2020). On June 3 2020, WHO Director-General Dr. Tedros said at a press conference that the WHO "Solidarity clinical trial" executive team agreed to continue the trial of hydroxychloroquine against COVID-19.

These different findings suggest that the drug regimens should be used with caution and urgent confirmation of anti-COVID-19 efficacy by randomized clinical trials in different age groups is needed.

\section{Lopinavir/Ritonavir and Interferons}

A report suggested that the anti-HIV drugs ritonavir and lopinavir may have a therapeutic effect on SARS-CoV-2. A member of the expert group of the National Health Commission, Dr. Guangfa Wang, who visited Wuhan and was infected by SARS-CoV-2, has recovered and discharged with the ritonavir/lopinavir therapy. The therapeutic effect may be due to their inhibitory effect on coronavirus endopeptidase C30 (Lin et al. 2020). Lopinavir and ritonavir were initially hypothesized to inhibit the 3-chymotrypsin-like protease of SARS and MERS, and appeared to be associated with improved clinical outcomes of patients with SARS in a non-randomized open-label trial (Zumla et al. 2016).

Lopinavir/ritonavir was subsequently recommended in the "Guideline on diagnosis and treatment of COVID-19 (Trial 7th edition)" issued by National Health Commission of China (2020b; in Chinese), and was also the first antiHIV drugs to be recommended. In a multicentre randomised open-label phase II trial in patients with COVID19 showed that early treatment with the triple combination of antiviral therapy with interferon beta-1b, lopinavir-ritonavir, and ribavirin is safe and highly effective in shortening the duration of virus shedding, decreasing cytokine responses, alleviating symptoms, and facilitating the discharge of patients with mild to moderate COVID19. Furthermore, the triple antiviral therapy rapidly rendered viral load negative in all specimens, thereby reducing infectiousness of the patient (Hung et al. 2020).

\section{Arbidol}

Arbidol is a broad-spectrum antiviral drug mainly used for respiratory diseases caused by influenza A and B viruses (Boriskin et al. 2008). Regarding coronaviruses, the potential therapeutic benefits of arbidol were firstly reported in 2008, when the concentration of arbidol was $50 \mu \mathrm{mol} / \mathrm{L}$, it had a significant inhibitory effect on SARS$\mathrm{CoV}$ infection in vitro (Khamitov et al. 2008). Recent research showed that arbidol can significantly inhibit SARS-CoV-2 infection at $10 \sim 30 \mu \mathrm{mol} / \mathrm{L}$ (Zhang $\mathrm{C}$ et al. 2020). Further verification of the anti SARS-CoV-2 efficacy in vivo is in need.

\section{Teicoplanin}

Teicoplanin, a glycopeptide antibiotic which has routinely been used in the clinic to treat bacterial infection with low toxicity, significantly inhibits the invasion of cells by Ebola virus, SARS-CoV and MERS-CoV, via specifically inhibiting the activity of cathepsin L (Zhou et al. 2016). A study tested the efficacy of teicoplanin against SARS-CoV-2 infection and found that teicoplanin potently prevented the entrance of SARS-CoV-2-Spike-pseudoviruses into the cytoplasm, with an $\mathrm{IC}_{50}$ of $1.66 \mu \mathrm{mol} / \mathrm{L}$ (Zhang $\mathrm{J}$ et al. 2020). Although the inhibitory effect upon the replication of wildtype viruses ex vivo and in vivo remains to be determined, preliminary results indicated that the potential antiviral activity of teicoplanin could be applied for the treatment of SARS-CoV-2 infection.

\section{Glycyrrhizic Acid}

Glycyrrhizic Acid is an extract of liquorice roots. Liquorice, Glycyrrhiza glabra, has long been employed against coughs and colds as well as to settle disturbed digestion. The diammonium glycyrrhizinate has anti-inflammatory activity and is used to treat liver damage caused by hepatitis B (Redeploying plant defences 2020).

Glycyrrhizic Acid has been used as an effective drug for the treatment of SARS, it can regulate immune function and exert antiviral effect, and it has a clear antiinflammatory mechanism (Hoever et al. 2005). ACE2 is the cell surface receptor of the SARS-CoV and SARSCoV-2. Recent studies have shown that Glycyrrhizic Acid can bind to ACE2 and thus has potential resistance to SARS-CoV-2 (Chai et al. 2020). Glycyrrhizin is the main 
active ingredient in licorice. Among the traditional Chinese medicine prescriptions used to treat COVID-19 in this epidemic, licorice is the most frequently used in all prevention and treatment programs, accounting for $6.7 \%$ (Wang YF et al. 2020).

\section{Bismuth Salts}

A study imply that the gastrointestinal tract is also the target of SARS-CoV-2 and the risk of further dissemination of this virus to healthy population through fecal-oral route cannot be omitted (Shu et al. 2020). Since bismuth potassium citrate (BPC) and ranitidine bismuth citrate (RBC) are already used to treat disorders in gastrointestinal tract, they may have the potential to be further developed for the prevention and treatment of COVID-19 (Shu et al. 2020). Future study should evaluate the inhibitory effect of BPC or RBC on SARS-CoV-2 replication in cells and in vivo.

\section{Clofazimine}

In an artificial intelligence approach fighting COVID-19 with repurposing drugs, AI system identified 80 marketed drugs with potential. Among them, 8 drugs (bedaquiline, brequinar, celecoxib, clofazimine, conivaptan, gemcitabine, tolcapone, and vismodegib) showed in vitro activities against the proliferation of a feline infectious peritonitis (FIP) virus in Fcwf-4 cells (Ke et al. 2020). The infection by FIP virus in cats presented similar features to the SARS infection such as pulmonary lesions in humans (Paltrinieri 2004). Clofazimine is an old hydrophobic riminophenazine, has a wide range of antimycobacterial activity ranging from leprosy to nontuberculous mycobacterial diseases (Riccardi et al. 2020). Taking the advantages of low price and long half-life and high drug concentration in the lungs, clofazimine with minimum adverse effects might be potential for treating COVID-19 (Ke et al. 2020).

\section{Network-Based Pharmacology Research}

Drug repurposing, represented as an effective drug discovery strategy from existing drugs, could significantly shorten the time and reduce the cost compared to de novo drug discovery and randomized clinical trials. However, experimental approaches for drug repurposing is costly and time-consuming. Computational approaches offer novel testable hypotheses for systematic drug repositioning before in vitro and in vivo verification (Zhou Y et al. 2020).

Network pharmacology is a research strategy for multitarget and multi-channel interactions of drugs. Starting from the integrity and systematicness of interactions between drug targets and diseases, it uses computer methods to model multi-target activities on the basis of multi-level networks of diseases, genes and drugs. At the same time, it studies the biological basis of drugs acting on the body, which is a powerful tool for medicine research (Yu et al. 2020).

Molecular docking is a computational tool for predicting the binding ability and binding mode of proteins and ligands (Ou et al. 2020). It is based on the "lock key model" of the interaction between proteins and small ligands, calculating and predicting the conformation and orientation of ligands at protein active sites, so as to judge the binding degree. It plays an important role in the target prediction of drug organisms (Duan et al. 2019).

Similar to SARS and MERS, SARS-COV-2 genome encodes non-structural proteins (such as 3-chymotrypsinlike protease, papain-like protease, helicase, and RNAdependent RNA polymerase), structural proteins (such as spike glycoprotein) and accessory proteins. The four nonstructural proteins are key enzymes in the viral life cycle, and the spike glycoprotein is indispensable for virus-cell receptor interactions during viral entry. These five proteins were therefore recognized as attractive targets to develop antiviral agents (Zumla et al. 2016; Li and De Clercq 2020).

\section{CLpro Inhibitor}

3CLpro is a cysteine protease responsible for the proteolysis of replicase polyproteins resulting in the formation of various functional proteins. Six approved anti-HIV-1 drugs were chosen to investigate their binding interactions with 3CLpro, and to evaluate their potential to become clinical drugs for SARS-CoV-2 infection. The results show that darunavir has the best binding affinity with SARS-CoV-2 3CLpro among all inhibitors, indicating it has the potential to become an anti-COVID-19 clinical drug (Sang et al. 2020).

Another computational analysis screened SARS-CoV-2 3CLpro compounds against an in-house library of 123 antiviral drugs. The results proposed that raltegravir, paritaprevir, bictegravir and Dolutegravir are excellent lead candidates for 3CLpro and they could become potential therapeutic drugs against SARS-CoV-2 (Rameez Jabeer et al. 2020).

\section{PLpro Inhibitor}

A study screened the FDA approved drugs targeting the papain-like protease (PLpro) in silico. In the docking studies, the homology model of the protease was built based on the SARS-CoV PLpro structure, and sixteen FDA approved drugs, including chloroquine and formoterol, was 
found to bind the target enzyme with significant affinity and good geometry, suggesting their potential to be utilized against the virus (Rimanshee et al. 2020). This also indicated that chloroquine may act as papain-like protease inhibitor.

\section{ACE2 Inhibitor}

Tennessee University used the world's most powerful supercomputer to conduct a virtual high-throughput screening of the ensemble docking. 77 ligands were calculated to bind strongly to either the S-protein: ACE2 interface-ligand binding complex or the binding-interface of the isolated S-protein, of which 24 had regulatory approval from the FDA or similar agencies. The identified small-molecules may be repurposed to limit viral recognition of host cells or disrupt host-virus interactions (Smith $M$ and Smith JC 2020). Another study using molecule docking showed that Mongolian medicine active ingredients forsythin and chlorogenic acid can be effectively combined with ACE2 and may be a potential candidate drug (Yu et al. 2020).

\section{TMPRSS2 Inhibitor}

Host cell entry of SARS-CoV-2 depends on the SARS$\mathrm{CoV}$ receptor ACE2 and can be blocked by a clinically proven inhibitor of the cellular serine protease TMPRSS2, which is employed by SARS-CoV-2 for S protein priming (Hoffmann et al. 2020). The finding highlights TMPRSS2 as a host cell factor that is critical for spread of several clinically relevant viruses, including influenza A viruses and coronaviruses. A serine protease inhibitor camostat mesylate, which blocks TMPRSS2 activity, has been approved in Japan for pancreatitis (Uno 2020). This compound or related ones with potentially increased antiviral activity could thus be considered for off-label treatment of SARS-CoV-2-infected patients.

\section{RdRp Inhibitor}

The viral $\mathrm{RdRp}$ is a promising target with polymerase inhibitors successfully used for the treatment of several viral diseases. A promising class of RdRp inhibitors are nucleoside analogues (NAs), small molecule drugs that are metabolized intracellularly into their active ribonucleotide $5^{\prime}$-triphosphate (RTP) forms and incorporated into the nascent viral RNA by error-prone viral RdRps. Several NAs currently being used for the treatment of other viral infections have been identified as potential anti-CoV candidates (Pruijssers and Denison 2019). Among these is the purine base analogue favipiravir that has broad spectrum activity against a number of RNA viruses and is currently licensed in Japan for use in the treatment of influenza virus (Du and Chen 2020). A recent study showed that favipiravir exerted an antiviral effect as a nucleotide analogue through a combination of chain termination, slowed RNA synthesis and lethal mutagenesis (Shannon et al. 2020). Clinical trials are currently ongoing in China, Italy, and the UK for the treatment of COVID-19 (Shannon et al. 2020).

\section{Antibody Drugs}

Antibody drugs have the advantages of high specificity, good safety, and long half-life in serum. It has shown good application prospects in the field of antivirals. Several candidate monoclonal antibody drugs are currently in the preclinical or clinical development stage for the treatment of chronic viral infections (AIDS) and acute viral infections (Ebola hemorrhagic fever) (Qiu et al. 2014; Caskey et al. 2015).

The analysis of the antigenic similarity of $\mathrm{S}$ protein between the SARS-CoV-2 and SARS-CoV by computer algorithms showed that both proteins had a cross-protected epitope (Qiu et al. 2020). Neutralizing antibodies targeting this cross-protected epitope may become broad-spectrum antiviral drugs for SARS-CoV-2 and SARS-CoV. SARS$\mathrm{CoV} \mathrm{S}$ protein mouse polyclonal serum can effectively inhibit the entry of SARS-CoV-2 virus into target cells (Zhou P et al. 2020) and the mouse polyclonal antibodies can effectively inhibit SARS-CoV-2 S protein-mediated cell entry (Walls et al. 2020). Furthermore, German scientists have found that serum from SARS-infected patients during recovery can prevent SARS-CoV-2 from infecting cells (Hoffmann et al. 2020). This indicates that there is indeed a cross-protected epitope between SARS-CoV and SARS-CoV-2, and the antibodies previously developed to treat SARS do have the potential to treat COVID-19.

Recent study has identified a SARS-CoV specific human monoclonal antibody CR3022, which could effectively bind to the receptor binding domain (RBD) of SARS-CoV-2 spike protein (Tian et al. 2020). Therefore, CR3022 has the potential to be developed as candidate therapeutic antibodies for SARS-CoV-2 infection.

There are 16 related drugs in the field of human coronavirus antibodies worldwide, mainly located in the United States (10) and China (3) (Li D et al. 2020). U.S. agencies have deployed related antibody and drug research in the fields of SARS-CoV and MERS-CoV. Among them, SAB301, an anti-MERS immunotherapy candidate drug developed by SAB Biotherapeutics, has entered the phase II clinical trial in 2019; The REGN-3048, REGN-3051, and REGN-3048-3051, which were developed by Regeneron Pharmaceuticals, are all candidates for anti-MERS immunotherapy, and entered the phase I clinical trial in 
2018. Drug development in Chinese institutions primarily targeted at SARS-CoV and is still in the discovery/exploration stage. Related products include hyperimmune globulins (Shenchen Weiguang Biological Products Co., Ltd.), immune globulin (Beijing Tiantan Biological Products Co., Ltd.) and human SARS immunoglobulin (Wuhan Biological Products Research Institute Co., Ltd.) (Li D et al. 2020).

In addition to artificial polyclonal or monoclonal antibodies, specific antibodies can also be obtained by direct infusion of plasma from COVID-19 patients during recovery. This method has achieved well effects in the treatment of SARS and highly pathogenic influenza viruses (Cheng et al. 2005; Zhou et al. 2007; Hung et al. 2011). But the resource of plasma during the recovery is limited, and the level of neutralizing antibody titer in the extracted plasma cannot be guaranteed, so its clinical application is also limited.

Recent study reports the isolation of two specific human monoclonal antibodies (MAbs) CA1 and CB6 from a convalescent COVID-19 patient. The study demonstrated CA1 and CB6 have potent SARS-CoV-2-specific neutralization activity in vitro against SARS-CoV-2. In addition, CB6 inhibited SARS-CoV-2 infection in rhesus monkeys at both prophylactic and treatment settings. Further structural studies revealed that $\mathrm{CB} 6$ recognizes an epitope that overlaps with angiotensin converting enzyme 2 (ACE2)binding sites in SARS-CoV-2 receptor binding domain (RBD), thereby interfering with the virus/receptor interactions by both steric hindrance and direct interfaceresidue competition (Shi et al. 2020). The results suggest CB6 deserves further clinical translation.

Researchers at Utrecht University, Erasmus Medical Center and Harbour BioMed (HBM) reported that they have identified a fully human monoclonal antibody that prevents the SARS-CoV-2 virus from infecting cultured cells. The discovery, published in Nature Communications, is an initial step towards developing a fully human antibody to treat or prevent the respiratory disease COVID-19 caused by the novel coronavirus SARS-CoV-2. The 47D11 antibody was found to potently inhibit infection of Vero E6 cells with SARS-S and SARS2-S pseudotyped VSV with IC50 values of 0.061 and $0.061 \mu \mathrm{g} / \mathrm{mL}$, respectively (Wang and Li 2020). This discovery provides a strong foundation for additional research to characterize this antibody and begin development as a potential COVID-19 treatment. Conventional therapeutic antibodies are first developed in other species and then must undergo additional work to 'humanize' them. The antibody was generated using Harbour BioMed's H2L2 transgenic mouse technology, which is "fully human source", allowing development to proceed more rapidly and reducing the potential for immune-related side effects.
The use of intravenous immunoglobulin to block FcR activation may be a viable option for the urgent treatment of pulmonary inflammation to prevent severe lung injury. Such treatment may also be combined with systemic antiinflammator drugs or corticosteroids (Fu Y et al. 2020).

In patients with COVID-19, a large number of T lymphocytes and mononuclear macrophages are activated, producing cytokines such as interleukin-6 (IL-6), which bind to the IL-6 receptor on the target cells, causing the cytokine storm and severe inflammatory responses in lungs and other tissues and organs (Xu and Han 2020). Tocilizumab, as a recombinant humanized anti-human IL-6 receptor monoclonal antibody, can bind to the IL-6 receptor with high affinity, thus preventing IL-6 itself from binding to its receptor, rendering it incapable of immune damage to target cells, and alleviating the inflammatory responses (Xu and Han 2020).

In March 2020, a retrospective evaluation of the COVID-19 clinical experience in China reported that, in the subset of patients who progressed to acute respiratory distress syndrome (ARDS), objectively sicker patients who received methylprednisolone had lower mortality rates than patients not receiving methylprednisolone (Wu et al. 2020). On 16 June, investigators on the COVID-19 RECOVERY trial revealed in a press release that participants with severe COVID-19 (2104) given 6 mg dexamethasone once daily had an 8\%-26\% lower mortality than 4321 participants given standard care. The findings support use of dexamethasone only for patients with hypoxaemia, not those with milder disease (Mahase 2020). Regarding potential side effects, the harm that has been noted in the past with steroids have been related to high doses. The known side effect profile of these drugs at high doses is well known. What was critical is getting the dose right with the right patients. The doses should be either a low or moderate dose, minimising the side effects while maximising the benefits. Despite concerns about the possibility of steroi associated complications, it would not be reasonable to delay use of a widely available treatment with a demonstrated mortality benefit.

\section{Traditional Chinese Medicine}

Traditional Chinese medicine (TCM), which mainly treat disease based on syndrome differentiation, has a long history in China and other Asian countries and plays an indispensable role in the prevention and treatment of severe epidemic diseases. During the SARS epidemic in 2003, the intervention of TCM has achieved remarkable therapeutic effect. A number of clinical practice results showed that traditional Chinese medicine plays significant role in the 
treatment of COVID-19, bringing new hope for the prevention and control of COVID-19 (Ren et al. 2020).

\section{Qingfei Paidu Decoction}

Qingfei Paidu Decoction (QPD) is an optimized combination of several classic recipes for treating exogenous fever caused by cold in Zhang Zhongjing's Treatise on Febrile and Miscellaneous Diseases in the Han Dynasty. QPD has been promoted as a general prescription in the diagnosis and treatment plan of COVID-19 in the 7th Version of Diagnosis and Treatment Protocol for COVID-19 in China (National Health Commission of the People's Republic of China 2020b). It was used to treat COVID-19 patients with mild, moderate and severe cases, and was also used reasonably with the consideration of the actual conditions of critically ill patients (National Health Commission of the People's Republic of China 2020a).

The network pharmacology analysis showed that QPD has an overall regulatory effect via multi-component and multi-target. The primary site of pharmacological action is the lung, as 16 herbs to lung meridian, which indicated that the decoction is mainly specific for lung diseases (Zhao et al. 2020). Through comprehensive analysis by liquid chromatography coupled with high resolution mass spectrometry (MS), a total of 129 compounds of QPD were putatively identified. Through constructing molecular networking of mass spectrometry data, 14 main clusters compounds were classified, in which exhibited specific patterns of flavonoids (45\%), glycosides (15\%), carboxylic acids (10\%), and saponins (5\%) (Yang et al. 2020). Among the 701 confirmed cases treated by QPD, 130 cases were cured and discharged, clinical symptoms of 51 cases disappeared, 268 cases of symptoms improved, and 212 cases with stable symptoms without aggravation (Ren et al. 2020). Although the effective cure rate of QPD against COVID-19 is over $90 \%$, as indicated by the authors, the control group without QPD treatment is absent and more data are needed to validate the high efficiency.

\section{Toujie Quwen Granules}

The prescription is developed by Tan Xinghua, a doctor of Guangzhou Eighth People's Hospital, based on his more than ten years of experience in clinical treatment of pneumonia, and adjusted according to the characteristics of COVID-19. The main ingredients include forsythia, honeysuckle, scutellaria, fritillaria, bupleurum, Artemisia annua, tangerine peel, poria, cardamom, etc. (Fu X et al. 2020). A statistical analysis of 121 patients was carried out, among whom the body temperature of 72 patients before taking the drug exceeded $37.3{ }^{\circ} \mathrm{C}$, and 108 cases of cough, and 108 cases of chest CT had inflammation and exudation. Six days after taking the drug, $84.72 \%$ (61 cases) patients' temperature returned to normal, $66.67 \%$ (72 cases) patients' cough symptoms disappeared, and other symptoms such as fatigue, anorexia, sore throat, etc. also had obvious curative effects. $74.07 \%$ (80 cases) patients had chest CT improved significantly. The results of the study suggest that the overall clinical symptoms of the patients have improved significantly, with a total effective rate of $94.21 \%$, while the total effective rate of the western medicine control group was $69.7 \%$ (Fu X et al. 2020).

The treatment mechanism of this prescription is speculated as follows. First, it can quickly improve clinical symptoms and quickly reduce fever. Second, it enhances the physical resistance. Third, it inhibits the release of inflammatory factors and reduces lung inflammation. The fourth, it adjusts the intestinal flora balance and keeps the stool flowing. However, this prescription is used only for mild and general pneumonia caused by SARS-CoV-2 infections, and there is no enough evidence to prove that it has a positive effect on severe patients. In addition, the drug is not suitable for prophylactic usage and should be taken under the guidance of doctor (State Council Information Office of the Peolple's Republic of China 2020).

\section{Qingfei Dayuan Granules and Chaihu Daxiong Mixture}

A prescription bupleurum chest bind decoction, named "Pneumonia 1" (later renamed Qingfei Dayuan Granules), was recommended by a traditional Chinese medicine doctor, Guoqiang Mei. Afterwards, another prescription "Potent Pneumonia 1" (later renamed Chaihu Daxiong Mixture) was recommended to patients with severe cough, sputum, and wheezing (Zhou S et al. 2020).

Hubei Provincial Hospital of Traditional Chinese Medicine treated 517 COVID-19 patients with combined western and Chinese medicine schemes such as "Pneumonia 1" and "Potent Pneumonia 1". 158 patients have been cured and discharged. Most of the patients have adopted the symptoms improved, the total clinical effective rate of integrated traditional Chinese and western medicine was more than $90 \%$, as declared by the hospital. On 23 February, Qingfei Dayuan Granules and Chaihu Daxiong Mixture were approved by the Hubei Provincial Drug Administration for prevention and treatment of COVID-19 (Hubei Daily 2020).

Molecular docking showed that the compounds with good binding power to SARS-CoV-2-RBD-ACE2 complex in Qingfei Dayuan granules were mainly come from Bupleuri Radix, Codonopsis Radix, Anemarrhenae Rhizoma, and Glycyrrhizae Radix et Rhizoma. Saikosaponin, glycyrrhizic acid, anemarsaponin had good binding power with SARS-CoV-2-S-RBD-ACE2, which may be potential 
active components against SARS-CoV-2. Conclusion Qingfei Dayuan Granules has the characteristics of multicomponents, multi-targets and multi-pathway regulation. Saikosaponin, glycyrrhizic acid, and anemarsaponin may be the potential active components against SARS-CoV-2. The mechanisms of its treatment against COVID-19 may be related to the regulation of the co-expressed genes with ACE2, inhibition of inflammation and immune related signaling pathways, and the destruction of the complex structure of SARS-CoV-2-S-RBD-ACE2 (Zhou S et al. 2020). Network pharmacology approach revealed that the main active ingredients of Chaihu Daxiong Mixture were $\beta$-sitosterol and 11 flavonoids. The core targets were CASP3, MAPK3, IL-6, MAPK8, IL-10, CXCL8, MAPK1 and IL-1B (Xiao et al. 2020).

\section{Huashi Baidu Granules}

Huashi Baidu Granules is based on actual experience of COVID-19 treatment in Jinyintan Hospital. Its functions may include eliminating inflammation and improving immunity, and may play an active role in the treatment of COVID-19 patients. Huashi Baidu Granules is the first approval drug of traditional Chinese medicine for the clinical treatment of COVID-19 (Chen et al. 2020).

Based on the efficacy of Huashi Baidu Recipe on 75 severe COVID-19 patients, significant improvement in symptoms and nucleic acid conversion to negative was reported. 452 cases of randomized control were performed in the cabin hospital, and the effect was also found. In an animal infection model, this recipe reduced the viral load of SARS-CoV-2 in the lungs by $30 \%$. The significant effects on the improvement of lung inflammation was also reported (China 2020-03-23). It is predicted that the main core compounds are quercetin, luteolin, kaempferol, begonin, naringenin, $\beta$-sitosterol, baicalein, etc., which play a key role in the entire network. The results of molecular docking showed that quercetin, luteolin, kaempferol had a good combination with 3CL hydrolase and ACE2 (Lai et al. 2020).

\section{Lianhuaqingwen}

Lianhuaqingwen (LH), a Chinese patent medicine composed of 13 herbs, has been used to treat influenza and exerted broad-spectrum antiviral effects on a series of influenza viruses and immune regulatory effects (Ding et al. 2017). It could significantly inhibit SARS-CoV-2 replication, alter the viral morphology and reduce the cytokine release from host cells, conferring anti-inflammatory activity in vitro ( $\mathrm{Li} \mathrm{R}$ et al. 2020). A retrospective analysis of clinical records was conducted in the SARSCoV-2 infected patients at Wuhan Ninth Hospital and CR
\& WISCO General Hospital, LH combination could significantly relieve cardinal symptoms and reduce the course of the COVID-19 (Cheng and Li 2020). Therefore, LH has been included in the Guideline for the Diagnosis and Treatment of COVID-19 (Trial 7th Edition) (National Health Commission of the People's Republic of China $2020 \mathrm{~b}$ ) and also recommended by 20 provincial health commissions including Hubei, Beijing, and Shanghai as well as National Administration of Traditional Chinese Medicine for the treatment of COVID-19. A prospective multicenter open-label randomized controlled trial on $\mathrm{LH}$ capsule in 283 confirmed cases with COVID-19 was conducted from February 2nd through February 15th, 2020 (Hu et al. 2020). The recovery rate was significantly higher in treatment group as compared with control group. The rate of improvement in chest computed tomographic manifestations and clinical cure was also higher in treatment group. However, both groups did not differ in the rate of conversion to severe cases or viral assay findings (Hu et al. 2020).

Recent clinical research reveals that LH capsules confer therapeutic effects on COVID-19 by improving the recovery rate of symptoms, shortening the time to symptom recovery, and improving the recovery of chest radiologic abnormalities (Hu et al. 2020). In light of the efficacy and safety profiles, LH capsules could be considered for the treatment of COVID-19. Future double-blind, prospective, randomized controlled trials are needed to fully evaluate the efficacy of LH capsules in a larger patient population.

\section{Perspective}

Although the genomic sequences and cryo-electron microscopy structure of SARS-CoV-2 have been obtained (Zhu et al. 2020), and the transmission routes are understood, the virus has the special characteristics of long incubation period, strong infectivity and quick conversion of severe disease, which have brought great difficulties to the prevention and control of COVID-19. Because of no specific drugs and vaccines have been available for the time being, more powerful treatment plan should be explored.

According to the existing research data, a batch of antiSARS-CoV/MERS-CoV/HIV clinical drugs have potential anti-SARS-CoV-2 activities, which brings hope for the treatment of COVID-19. Some drugs have been approved by clinical trials or already listed. The strategy of repurposing of existing drugs for the clinical management of COVID-19 plays an important role in the current fight against SARS-CoV-2. Most of the clinical effects of these potential anti-SARS-CoV-2 drugs have yet to be verified. Prediction and screening of possible drugs according to the 
structure of the virus is a fast and efficient screening method. Although some chemical drugs have been tested in vitro and have obtained anti-SARS-CoV-2 effects, how is the antiviral activity in vivo remains to be confirmed. At the same time, it should give full play to the advantages of Traditional Chinese Medicine in syndrome differentiation, the whole therapeutic effect, as well as the complication and fatality rate reduction.

In conclusion, although the repurposing existing antiviral agents, network-based pharmacology research, antibody drugs and Traditional Chinese Medicine have showed obvious anti-SARS-CoV-2 efficacy in vitro and in vivo, clinical trials are indispensable to determine the safety and efficacy of all these antivirals in a large patient population with COVID-19. A lot of them have been on the way and clinical application prospect is expected (Table 1).

Acknowledgements This work was supported by grants from the National Key Research and Development Program of China (2018YFE0204503) and Natural Science Foundation of Guangdong Province (2018B030312010), as well as the Guangzhou Healthcare Collaborative Innovation Major Project (201803040004 and 201803040007).

\section{Compliance with Ethical Standards}

Conflict of interest The authors declare that they have no conflict of interest.

Animal and Human Rights Statement This article does not contain any studies with human or animal subjects performed by any of the authors.

\section{References}

Agostini ML, Andres EL, Sims AC, Graham RL, Sheahan TP, Lu X, Smith EC, Case JB, Feng JY, Jordan R, Ray AS, Cihlar T, Siegel D, Mackman RL, Clarke MO, Baric RS, Denison MR (2018) Coronavirus susceptibility to the antiviral remdesivir (GS-5734) is mediated by the viral polymerase and the proofreading exoribonuclease. eBio 9:e00221-00218

Boriskin YS, Leneva IA, Pécheur EI, Polyak SJ (2008) Arbidol: a broad-spectrum antiviral compound that blocks viral fusion. Curr Med Chem 15:997-1005

Boulos A, Rolain JM, Raoult D (2004) Antibiotic susceptibility of Tropheryma whipplei in MRC5 cells. Antimicrob Agents Chemother 48:747-752

Boulware DR, Pullen MF, Bangdiwala AS, Pastick KA, Lofgren SM, Okafor EC, Skipper CP, Nascene AA, Nicol MR (2020) A randomized trial of hydroxychloroquine as postexposure prophylaxis for Covid-19. N Engl J Med 383:517-525

Caskey M, Klein F, Lorenzi JCC, Seaman MS, West AP Jr, Buckley N, Kremer G, Nogueira L, Braunschweig M, Scheid JF, Horwitz JA, Shimeliovich I, Ben-Avraham S, Witmer-Pack M, Platten M, Lehmann C, Burke LA, Hawthorne T, Gorelick RJ, Walker BD, Keler T, Gulick RM, Fätkenheuer G, Schlesinger SJ, Nussenzweig MC (2015) Viraemia suppressed in HIV-1-infected humans by broadly neutralizing antibody 3BNC117. Nature 522:487-491

Chai X, Hu L, Zhang Y, Han W, Lu Z, Ke A, Zhou J, Shi G, Fang N, Fan J, Cai J, Fan J, Lan F (2020) Specific ACE2 expression in cholangiocytes may cause liver damage after 2019-nCoV infection. bioRxiv. https://doi.org/10.1101/2020.02.03.931766: 2020.2002.2003.931766

Chan JFW, Kok KH, Zhu Z, Chu H, To KK-W, Yuan S, Yuen KY (2020) Genomic characterization of the 2019 novel humanpathogenic coronavirus isolated from a patient with atypical pneumonia after visiting Wuhan. Emerg Microbes Infect 9:221-236

Chen L, Ge G, Rong Y, Fu W, Zheng M, Zhao Y, Yuan W, Luan X, Zhang L, Zhang H, Chen H (2020) Application and research progress of traditional Chinese medicine in prevention and treatment of corona virus disease 2019. Acad J Shanghai Univ Tradit Chin Med 34:1-8 (in Chinese)

Cheng D, Li Y (2020) Clinical effectiveness and case analysis in 54 NCP patients treated with lanhuaqingwen granules. World Chin Med 15:150-154

Cheng Y, Wong R, Soo YO, Wong WS, Lee CK, Ng MH, Chan P, Wong KC, Leung CB, Cheng G (2005) Use of convalescent plasma therapy in SARS patients in Hong Kong. Eur J Clin Microbiol Infect Dis 24:44-46

Cohen J (2020) Can an anti-HIV combination or other existing drugs outwit the new coronavirus? https://www.sciencemag.org/news/ 2020/01/can-anti-hiv-combination-or-other-existing-drugs-out wit-new-coronavirus. Accessed 31 March

Ding Y, Zeng L, Li R, Chen Q, Zhou B, Chen Q, Cheng PL, Yutao W, Zheng J, Yang Z, Zhang F (2017) The Chinese prescription lianhuaqingwen capsule exerts anti-influenza activity through the inhibition of viral propagation and impacts immune function. BMC Complement Altern Med 17:130

Du YX, Chen XP (2020) Favipiravir: pharmacokinetics and concerns about clinical trials for 2019-nCoV infection. Clin Pharmacol Ther 108:242-247

Duan H, Zhai KF, Khan GJ, Zhou J, Cao TY, Wu YQ, Zhou YR, Cao WG, Gao GZ, Shan LL (2019) Revealing the synergistic mechanism of multiple components in compound Fengshiding capsule for rheumatoid arthritis therapeutics by network pharmacology. Curr Mol Med 19:303-314

Dyall J, Coleman CM, Hart BJ, Venkataraman T, Holbrook MR, Kindrachuk J, Johnson RF, Olinger GG Jr, Jahrling PB, Laidlaw M, Johansen LM, Lear-Rooney CM, Glass PJ, Hensley LE, Frieman MB (2014) Repurposing of clinically developed drugs for treatment of Middle East respiratory syndrome coronavirus infection. Antimicrob Agents Chemother 58:4885-4893

Fu X, Lin L, Tan X (2020) Clinical study on treatment of cases of COVID-19 with Toujie Quwen granules. Chin J Exp Tradit Med Formulae 26:44-48 (in Chinese)

Fu Y, Cheng Y, Wu Y (2020) Understanding SARS-CoV-2-mediated inflammatory responses: from mechanisms to potential therapeutic tools. Virol Sin 35:266-271

Gao K, Nguyen DD, Wang R, Wei G-W (2020) Machine intelligence design of 2019-nCoV drugs. bioRxiv. https://doi.org/10.1101/ 2020.01.30.927889:2020.2001.2030.927889

Gorbalenya AE, Baker SC, Baric RS, de Groot RJ, Drosten C, Gulyaeva AA, Haagmans BL, Lauber C, Leontovich AM, Neuman BW, Penzar D, Perlman S, Poon LLM, Samborskiy D, Sidorov IA, Sola I, Ziebuhr J (2020) The species Severe acute respiratory syndrome-related coronavirus: classifying 2019-nCoV and naming it SARS-CoV-2. Nat Microbiol 5:536-544

Guo D (2020) Old weapon for new enemy: drug repurposing for treatment of newly emerging viral diseases. Virol Sin $35: 253-255$ 
Harrison C (2020) Coronavirus puts drug repurposing on the fast track. Nat Biotechnol 38:379-381

Hoever G, Baltina L, Michaelis M, Kondratenko R, Baltina L, Tolstikov GA, Doerr HW, Cinatl J Jr (2005) Antiviral activity of glycyrrhizic acid derivatives against SARS-coronavirus. J Med Chem 48:1256-1259

Hoffmann M, Kleine-Weber H, Schroeder S, Krüger N, Herrler T, Erichsen S, Schiergens TS, Herrler G, Wu NH, Nitsche A, Müller MA, Drosten C, Pöhlmann S (2020) SARS-CoV-2 cell entry depends on ACE2 and TMPRSS 2 and is blocked by a clinically proven protease inhibitor. Cell 181:271-280.e278

Holshue ML, DeBolt C, Lindquist S, Lofy KH, Wiesman J, Bruce H, Spitters C, Ericson K, Wilkerson S, Tural A, Diaz G, Cohn A, Fox L, Patel A, Gerber SI, Kim L, Tong S, Lu X, Lindstrom S, Pallansch MA, Weldon WC, Biggs HM, Uyeki TM, Pillai SK (2020) First case of 2019 novel coronavirus in the United States. N Engl J Med 382:929-936

Hu K, Guan WJ, Bi Y, Zhang W, Li L, Zhang B, Liu Q, Song Y, Li X, Duan Z, Zheng Q, Yang Z, Liang J, Han M, Ruan L, Wu C, Zhang Y, Jia ZH, Zhong NS (2020) Efficacy and safety of Lianhuaqingwen capsules, a repurposed Chinese herb, in patients with coronavirus disease 2019: a multicenter, prospective, randomized controlled trial. Phytomedicine. https://doi.org/10. 1016/j.phymed.2020.153242:153242

Huang C, Wang Y, Li X, Ren L, Zhao J, Hu Y, Zhang L, Fan G, Xu J, Gu X, Cheng Z, Yu T, Xia J, Wei Y, Wu W, Xie X, Yin W, Li H, Liu M, Xiao Y, Gao H, Guo L, Xie J, Wang G, Jiang R, Gao Z, Jin Q, Wang J, Cao B (2020) Clinical features of patients infected with 2019 novel coronavirus in Wuhan, China. Lancet 395:497-506

Huang M, Li M, Xiao F, Pang P, Liang J, Tang T, Liu S, Chen B, Shu J, You Y, Li Y, Tang M, Zhou J, Jiang G, Xiang J, Hong W, He S, Wang Z, Feng J, Lin C, Ye Y, Wu Z, Li Y, Zhong B, Sun R, Hong Z, Liu J, Chen H, Wang X, Li Z, Pei D, Tian L, Xia J, Jiang S, Zhong N, Shan H (2020) Preliminary evidence from a multicenter prospective observational study of the safety and efficacy of chloroquine for the treatment of COVID-19. Natl Sci Rev. https://doi.org/10.1093/nsr/nwaa113

Hubei Daily (2020) Hubei version of "Pneumonia No. 1" and "Powerful Pneumonia No. 1" hospital preparations approved for record. http://news.cnhubei.com/content/2020-02/24/content_ 12776800.html?spm=zm1033-001.0.0.1.fgF5V7. Accessed 23 Feb 2020 (in Chinese)

Hung IF, To KK, Lee C-K, Lee K-L, Chan K, Yan W-W, Liu R, Watt C-L, Chan W-M, Lai K-Y, Koo C-K, Buckley T, Chow FL, Wong K-K, Chan H-S, Ching C-K, Tang BS, Lau CC, Li IW, Liu SH, Chan KH, Lin CK, Yuen KY (2011) Convalescent plasma treatment reduced mortality in patients with severe pandemic influenza A (H1N1) 2009 virus infection. Clin Infect Dis $52: 447-456$

Hung IF, Lung KC, Tso EY, Liu R, Chung TW, Chu MY, Ng YY, Lo J, Chan J, Tam AR, Shum HP, Chan V, Wu AK, Sin KM, Leung WS, Law WL, Lung DC, Sin S, Yeung P, Yip CC, Zhang RR, Fung AY, Yan EY, Leung KH, Ip JD, Chu AW, Chan WM, Ng AC, Lee R, Fung K, Yeung A, Wu TC, Chan JW, Yan WW, Chan WM, Chan JF, Lie AK, Tsang OT, Cheng VC, Que TL, Lau CS, Chan KH, To KK, Yuen KY (2020) Triple combination of interferon beta- $1 \mathrm{~b}$, lopinavir-ritonavir, and ribavirin in the treatment of patients admitted to hospital with COVID-19: an open-label, randomised, phase 2 trial. Lancet 395:1695-1704

Ke YY, Peng TT, Yeh TK, Huang WZ, Chang SE, Wu SH, Hung HC, Hsu TA, Lee SJ, Song JS, Lin WH, Chiang TJ, Lin JH, Sytwu HK, Chen CT (2020) Artificial intelligence approach fighting COVID-19 with repurposing drugs. Biomed J. https://doi.org/10. 1016/j.bj.2020.05.001
Khamitov RA, Loginova SI, Shchukina VN, Borisevich SV, Maksimov VA, Shuster AM (2008) Antiviral activity of arbidol and its derivatives against the pathogen of severe acute respiratory syndrome in the cell cultures. Vopr Virusol 53:9-13

Ko WC, Rolain JM, Lee NY, Chen PL, Huang CT, Lee PI, Hsueh PR (2020) Arguments in favour of remdesivir for treating SARSCoV-2 infections. Int J Antimicrob Agents. https://doi.org/10. 1016/j.ijantimicag.2020.105933:105933

Lai Q, Liang A, He M, Huang X, Wu W (2020) Pharmacological mechanism and network pharmacology research of Huashibaidu formula in treating COVID-19. Nat Prod Res Dev 32:909-919

Li G, De Clercq E (2020) Therapeutic options for the 2019 novel coronavirus (2019-nCoV). Nat Rev Drug Discov 19:149-150

Li D, Lü L, Yang Y (2020) The research status and development trend of global human coronavirus antibody field. China Biotechnol 40:65-70

Li R, Hou Y, Huang J, Pan W, Ma Q, Shi Y, Li C, Zhao J, Jia Z, Jiang H, Zheng K, Huang S, Dai J, Li X, Hou X, Wang L, Zhong N, Yang Z (2020) Lianhuaqingwen exerts anti-viral and antiinflammatory activity against novel coronavirus (SARS-CoV-2). Pharmacol Res 156:104761

Lin S, Shen R, Guo X (2020) Molecular modeling evaluation of the binding abilities of ritonavir and lopinavir to wuhan pneumonia coronavirus proteases. bioRxiv. https://doi.org/10.1101/2020.01. 31.929695:2020.2001.2031.929695

Mahase E (2020) Covid-19: low dose steroid cuts death in ventilated patients by one third, trial finds. BMJ 369:m2422

Mehra MR, Desai SS, Ruschitzka F, Patel AN (2020) Hydroxychloroquine or chloroquine with or without a macrolide for treatment of COVID-19: a multinational registry analysis. Lancet. https://doi.org/10.1016/S0140-6736(20)31180-6

National Health Commission of the People's Republic of China (2020a) Transcript of the press conference of the State Council Information Office on March 23, 2020

National Health Commission of the People's Republic of China (2020b) Guideline on diagnosis and treatment of COVID-19 (Trial 7th edition). http://www.nhc.gov.cn/xcs/zhengcwj/ 202003/46c9294a7dfe4cef80dc7f5912eb1989.shtml. Accessed 3 March (in Chinese)

National Institutes of Health (NIH) (2020) NIH clinical trial shows remdesivir accelerates recovery from advanced COVID-19. https://www.nih.gov/news-events/news-releases/nih-clinicaltrial-shows-remdesivir-accelerates-recovery-advanced-covid-19. Accessed 29 Apr 2020

Ou J, Zhou Z, Dai R, Zhang J, Lan W, Zhao S, Wu J, Seto D, Cui L, Zhang G, Zhang Q (2020) Emergence of RBD mutations in circulating SARS-CoV-2 strains enhancing the structural stability and human ACE2 receptor affinity of the spike protein. bioRxiv. https://doi.org/10.1101/2020.03.15.991844:2020.2003. 2015.991844

Paltrinieri S (2004) Human severe acute respiratory syndrome (SARS) and feline coronaviroses. J Feline Med Surg 6:131-132

Pruijssers AJ, Denison MR (2019) Nucleoside analogues for the treatment of coronavirus infections. Curr Opin Virol 35:57-62

Qiu X, Wong G, Audet J, Bello A, Fernando L, Alimonti JB, Fausther-Bovendo H, Wei H, Aviles J, Hiatt E, Johnson A, Morton J, Swope K, Bohorov O, Bohorova N, Goodman C, Kim D, Pauly MH, Velasco J, Pettitt J, Olinger GG, Whaley K, Xu B, Strong JE, Zeitlin L, Kobinger GP (2014) Reversion of advanced Ebola virus disease in nonhuman primates with ZMapp. Nature 514:47-53

Qiu T, Mao T, Wang Y, Zhou M, Qiu J, Wang J, Xu J, Cao Z (2020) Identification of potential cross-protective epitope between a new type of coronavirus (2019-nCoV) and severe acute respiratory syndrome virus. J Genet Genomics. https://doi.org/10. 1016/j.jgg.2020.01.003 
Rameez Jabeer K, Rajat KJ, Gizachew Muluneh A, Monika J, Ekampreet S, Amita P, Rashmi Prabha S, Jayaraman M, Amit Kumar S (2020) Targeting novel coronavirus 2019: a systematic drug repurposing approach to identify promising inhibitors against 3C-like proteinase and $2^{\prime}$-o-ribose methyltransferase. ChemRxiv 1:1. https://doi.org/10.26434/chemrxiv.11888730.v1

Raoult D, Drancourt M, Vestris G (1990) Bactericidal effect of doxycycline associated with lysosomotropic agents on Coxiella burnetii in P388D1 cells. Antimicrob Agents Chemother 34:1512-1514

Raoult D, Houpikian P, Tissot Dupont H, Riss JM, Arditi-Djiane J, Brouqui P (1999) Treatment of Q fever endocarditis: comparison of 2 regimens containing doxycycline and ofloxacin or hydroxychloroquine. Arch Intern Med 159:167-173

Redeploying plant defences (2020). Nat Plants 6:177

Ren JL, Zhang AH, Wang XJ (2020) Traditional Chinese medicine for COVID-19 treatment. Pharmacol Res 155:104743

Riccardi N, Giacomelli A, Canetti D, Comelli A (2020) Clofazimine: an old drug for never-ending diseases. Future Microbiol 15:557-566

Rimanshee A, Amit D, Vishal P, Mukesh K (2020) Potential inhibitors against papain-like protease of novel coronavirus (SARS-CoV-2) from FDA approved drugs. ChemRxiv. https:// doi.org/10.26434/chemrxiv.11860011.v2

Rolain JM, Colson P, Raoult D (2007) Recycling of chloroquine and its hydroxyl analogue to face bacterial, fungal and viral infections in the 21 st century. Int $\mathrm{J}$ Antimicrob Agents 30:297-308

Sang P, Tian S, Meng Z, Yang L (2020) Insight derived from molecular docking and molecular dynamics simulations into the binding interactions between HIV-1 protease inhibitors and SARS-CoV-2 3CLpro. ChemRxiv. https://doi.org/10.26434/ chemrxiv.11932995.v1

Savarino A, Boelaert JR, Cassone A, Majori G, Cauda R (2003) Effects of chloroquine on viral infections: an old drug against today's diseases? Lancet Infect Dis 3:722-727

Savarino A, Di Trani L, Donatelli I, Cauda R, Cassone A (2006) New insights into the antiviral effects of chloroquine. Lancet Infect Dis 6:67-69

Shannon A, Selisko B, Le N, Huchting J, Touret F, Piorkowski G, Fattorini V, Ferron F, Decroly E, Meier C, Coutard B, Peersen O, Canard B (2020) Favipiravir strikes the SARS-CoV-2 at its Achilles heel, the RNA polymerase. bioRxiv. https://doi.org/10. 1101/2020.05.15.098731

Sheahan TP, Sims AC, Leist SR, Schäfer A, Won J, Brown AJ, Montgomery SA, Hogg A, Babusis D, Clarke MO, Spahn JE, Bauer L, Sellers S, Porter D, Feng JY, Cihlar T, Jordan R, Denison MR, Baric RS (2020) Comparative therapeutic efficacy of remdesivir and combination lopinavir, ritonavir, and interferon beta against MERS-CoV. Nat Commun 11:222-222

Shi R, Shan C, Duan X, Chen Z, Liu P, Song J, Song T, Bi X, Han C, Wu L, Gao G, Hu X, Zhang Y, Tong Z, Huang W, Liu WJ, Wu G, Zhang B, Wang L, Qi J, Feng H, Wang F-s, Wang Q, Gao GF, Yuan Z, Yan J (2020) A human neutralizing antibody targets the receptor binding site of SARS-CoV-2. Nature. https://doi.org/10. 1038/s41586-020-2381-y

Shu T, Huang M, Wu D, Ren Y, Zhang X, Han Y, Mu J, Wang R, Qiu Y, Zhang DY, Zhou X (2020) SARS-Coronavirus-2 Nsp13 possesses NTPase and RNA helicase activities that can be inhibited by bismuth salts. Virol Sin 35:321-329

Smith M, Smith JC (2020) Repurposing therapeutics for COVID-19: Supercomputer-based docking to the SARS-CoV-2 viral spike protein and viral spike protein-human ACE2 interface. ChemRxiv. https://doi.org/10.26434/chemrxiv.11871402.v4

State Council Information Office of the Peolple's Republic of China (2020) The 25th press conference of Guangdong Provincial
Government Information Office for epidemic prevention and control. http://www.scio.gov.cn/xwFbh/gssxwfbh/xwfbh/guang dong/Document/1676688/1676688.htm. Accessed 29 Feb 2020 (in Chinese)

Tchesnokov EP, Feng JY, Porter DP, Götte M (2019) Mechanism of inhibition of Ebola virus RNA-dependent RNA polymerase by remdesivir. Viruses 11:326

Tian X, Li C, Huang A, Xia S, Lu S, Shi Z, Lu L, Jiang S, Yang Z, Wu Y, Ying T (2020) Potent binding of 2019 novel coronavirus spike protein by a SARS coronavirus-specific human monoclonal antibody. bioRxiv. https://doi.org/10.1101/2020.01.28. 923011:2020.2001.2028.923011

Uno Y (2020) Camostat mesilate therapy for COVID-19. Intern Emerg Med. https://doi.org/10.1007/s11739-020-02345-9:1-2

Vincent MJ, Bergeron E, Benjannet S, Erickson BR, Rollin PE, Ksiazek TG, Seidah NG, Nichol ST (2005) Chloroquine is a potent inhibitor of SARS coronavirus infection and spread. Virol J 2:69-69

Walls AC, Park Y-J, Tortorici MA, Wall A, McGuire AT, Veesler D (2020) Structure, function, and antigenicity of the SARS-CoV-2 spike glycoprotein. Cell. https://doi.org/10.1016/j.cell.2020.02. 058

Wang C, Li W (2020) A human monoclonal antibody blocking SARS-CoV-2 infection. Nat Commun 11:2251

Wang M, Cao R, Zhang L, Yang X, Liu J, Xu M, Shi Z, Hu Z, Zhong W, Xiao G (2020) Remdesivir and chloroquine effectively inhibit the recently emerged novel coronavirus (2019-nCoV) in vitro. Cell Res 30:269-271

Wang YF, Qiu M, Pei H, Yan E, Zhang Q, Liu S, Zou H, Xiong L, Ye G, Wen T (2020) Analysis on the prescription and medication Law of differential treatment of COVID-19 with traditional Chinese Medicine. World Chin Med. https://doi.org/10.3969/j. issn.1673-7202.2020.03.008 (in Chinese)

Wang YM, Zhang D, Du G, Du R, Zhao J, Jin Y, Fu S, Gao L, Cheng Z, Lu Q, Hu Y, Luo G, Wang K, Lu Y, Li H, Wang S, Ruan S, Yang C, Mei C, Wang Y, Ding D, Wu F, Tang X, Ye X, Ye Y, Liu B, Yang J, Yin W, Wang A, Fan G, Zhou F, Liu Z, Gu X, Xu J, Shang L, Zhang Y, Cao L, Guo T, Wan Y, Qin H, Jiang Y, Jaki T, Hayden FG, Horby PW, Cao B, Wang C (2020) Remdesivir in adults with severe COVID-19: a randomised, double-blind, placebo-controlled, multicentre trial. Lancet. https://doi.org/10.1016/S0140-6736(20)31022-9

Warren TK, Jordan R, Lo MK, Ray AS, Mackman RL, Soloveva V, Siegel D, Perron M, Bannister R, Hui HC, Larson N, Strickley R, Wells J, Stuthman KS, Van Tongeren SA, Garza NL, Donnelly G, Shurtleff AC, Retterer CJ, Gharaibeh D, Zamani R, Kenny T, Eaton BP, Grimes E, Welch LS, Gomba L, Wilhelmsen CL, Nichols DK, Nuss JE, Nagle ER, Kugelman JR, Palacios G, Doerffler E, Neville S, Carra E, Clarke MO, Zhang L, Lew W, Ross B, Wang Q, Chun K, Wolfe L, Babusis D, Park Y, Stray KM, Trancheva I, Feng JY, Barauskas O, Xu Y, Wong P, Braun MR, Flint M, McMullan LK, Chen SS, Fearns R, Swaminathan S, Mayers DL, Spiropoulou CF, Lee WA, Nichol ST, Cihlar T, Bavari S (2016) Therapeutic efficacy of the small molecule GS5734 against Ebola virus in rhesus monkeys. Nature 531:381-385

White NJ, Pukrittayakamee S, Hien TT, Faiz MA, Mokuolu OA, Dondorp AM (2014) Malaria. Lancet 383:723-735

World Health Organization (WHO) (2020) Coronavirus disease (COVID2019) situation reports. https://www.who.int/emergencies/diseases/ novel-coronavirus-2019/situation-reports. Accessed 4 Sept 2020

Wu C, Chen X, Cai Y, Xia J, Zhou X, Xu S, Huang H, Zhang L, Zhou X, Du C, Zhang Y, Song J, Wang S, Chao Y, Yang Z, Xu J, Zhou X, Chen D, Xiong W, Xu L, Zhou F, Jiang J, Bai C, Zheng J, Song Y (2020) Risk factors associated with acute respiratory 
distress syndrome and death in patients with coronavirus disease 2019 pneumonia in Wuhan, China. JAMA Intern Med 180:1-11

Xiao Z, Liu C, Lu S, Cai J, Xu F (2020) The mechanism study on Chaihudaxiong mixture in the treatment of coronavirus disease 2019 with network pharmacology approach. J Pharm Pract 38:289-295 (in Chinese)

$\mathrm{Xu} \mathrm{X}$, Han M (2020) Effective treatment of severe COVID-19 patients with tocilizumab. Proc Natl Acad Sci USA 117:10970-10975

Yang R, Liu H, Bai C, Wang Y, Zhang X, Guo R, Wu S, Wang J, Leung E, Chang H, Li P, Liu T, Wang Y (2020) Chemical composition and pharmacological mechanism of Qingfei Paidu Decoction and Ma Xing Shi Gan Decoction against Coronavirus Disease 2019 (COVID-19): in silico and experimental study. Pharmacol Res 157:104820

Yu JW, Wang L, Bao LD (2020) Exploring the active compounds of traditional mongolian medicine in intervention of novel coronavirus (COVID-19) based on molecular docking method. J Funct Foods 71:104016

Zhang C, Chen SB, Jie Zhang, Guo Y (2020) Analysis of chemical drugs applied for clinical trial for the treatment of COVID-19. Acta Pharm Sin 55:355-365

Zhang J, Ma X, Yu F, Liu J, Zou F, Pan T, Zhang H (2020) Teicoplanin potently blocks the cell entry of 2019-nCoV. bioRxiv. https://doi.org/10.1101/2020.02.05.935387:2020.2002. 2005.935387

Zhao J, Tian S, Yang J, Liu J, Zhang W (2020) Investigating the mechanism of Qing-Fei-Pai-Du-Tang for the treatment of Novel Coronavirus Pneumonia by networkpharmacology. Chin Tradit Herbal Drugs 51:829-835
Zhou B, Zhong N, Guan Y (2007) Treatment with convalescent plasma for influenza A (H5N1) infection. N Engl J Med 357:1450-1451

Zhou N, Pan T, Zhang J, Li Q, Zhang X, Bai C, Huang F, Peng T, Zhang J, Liu C, Tao L, Zhang H (2016) Glycopeptide antibiotics potently inhibit cathepsin $\mathrm{L}$ in the late endosome/lysosome and block the entry of Ebola Virus, Middle East Respiratory Syndrome Coronavirus (MERS-CoV), and Severe Acute Respiratory Syndrome Coronavirus (SARS-CoV). J Biol Chem 291:9218-9232

Zhou P, Yang X, Wang X, Hu B, Zhang L, Zhang W, Si H, Zhu Y, Li B, Huang C, Chen H, Chen J, Luo Y, Guo H, Jiang R, Liu M, Chen Y, Shen X, Wang X, Zheng X, Zhao K, Chen Q, Deng F, Liu L, Yan B, Zhan F, Wang Y, Xiao G, Shi Z (2020) A pneumonia outbreak associated with a new coronavirus of probable bat origin. Nature 579:270-273

Zhou S, Li W, Ai Z, Wang L, Ba Y (2020) Investigating mechanism of Qingfei Dayuan Granules for treatment of COVID-19 based on network pharmacology and molecular docking. Chin Tradit Herbal Drugs 51:1804-1813

Zhou Y, Hou Y, Shen J, Huang Y, Martin W (2020) Network-based drug repurposing for novel coronavirus 2019-nCoV/SARS-CoV2. Cell Discov 6:14

Zhu N, Zhang D, Wang W, Li X, Yang B, Song J, Zhao X, Huang B, Shi W, Lu R, Niu P, Zhan F, Ma X, Wang D, Xu W, Wu G, Gao GF, Tan W (2020) A Novel coronavirus from patients with pneumonia in China, 2019. N Engl J Med 382:727-733

Zumla A, Chan JF, Azhar EI, Hui DS, Yuen KY (2016) Coronaviruses-drug discovery and therapeutic options. Nat Rev Drug Discov 15:327-347 